\title{
An Analysis of a Persian Archery manuscript written by Kapur Čand
}

\author{
${ }^{1}$ Independent researcher (Australia) \\ 2 Independent researcher (Germany)
}

Bede DWYER ${ }^{1 *} \&$ Manouchehr MOSHTAGH KHORASANI ${ }^{2}$

Received: 14/01/2013; Accepted: 11/04/2013; Published: 29/04/2013.

\begin{abstract}
The present article deals with an analysis of an undated Persian archery manuscript titled Resāle-ye Kamāndāri [Archery Manuscript] written by Kapur Čand. It is written in Persian and judging by the style it should have been written by a Persian. Persian archery manuscripts provide useful information on the usage of a contemporary Persian composite bow. First the article describes where the archery manuscript was found and collected. Then it describes the qualities of an archer in ten points. The next part of the article presents the characteristics of a Persian composite bow as described in the manuscript. Then the article discusses the suggested materials for making a bowstring. The next part of the manuscript deals with the materials used for making an arrow and useful information in the manuscript for bracing a Persian bow. The final part of the article explains different shooting techniques that can be used in shooting with a Persian composite bow.
\end{abstract}

Keywords: Persian martial arts; Historical martial arts; Persian bow; composite bow; archery.

\section{Análisis de un manuscrito persa de tiro con arco escrito por Kapur Čand \\ Resumen}

El presente artículo analiza un manuscrito persa no datado sobre tiro con arco titulado Resāle-ye Kamāndāri [Manuscrito de Tiro con Arco] escrito por Kapur Čand. Está escrito en persa y según su estilo debió ser escrito por un persa. Los manuscritos persas sobre tiro con arco aportan información útil sobre el uso del arco compuesto en su época. El artículo describe dónde se encontró y colectó el manuscrito. A continuación explica las cualidades de un arquero en diez puntos. La siguiente parte presenta las características de un arco recurvado persa tal y como es descrito en el manuscrito. Se discuten también los materiales sugeridos para elaborar la cuerda del arco. La siguiente parte del manuscrito trata de los materiales utilizados para hacer una flecha $y$ proporciona una valiosa información sobre cómo tensar un arco persa. La parte final del artículo explica las diferentes técnicas de disparo que pueden utilizarse para disparar con un arco compuesto persa.

Palabras clave: Artes marciales persas; Artes marciales históricas; Arco persa; arco compuesto; tiro con arco.

\section{Análise de um manuscrito persa sobre o tiro com arco escrito por Kapur Čand}

\section{Resumo}

0 presente artigo analisa um manuscrito persa não datado sobre o tiro com arco, intitulado Resāle-ye Kamāndāri (Manuscrito de Tiro com Arco), escrito por Kapur Čand. Está escrito em persa e, segundo o estilo, deverá ter sido escrito por um persa. Os manuscritos persas sobre o tiro com arco apresentam informação interessante e útil sobre o uso do arco construído na época. 0 artigo descreve onde se encontrou e recolheu o manuscrito. Posteriormente, o texto explica as qualidades de um arqueiro em dez pontos. 0 artigo apresenta igualmente as características de um arco recurvado persa tal como é descrito no manuscrito. 0 artigo discute também os materiais utilizados para elaborar a corda do arco. Uma outra parte do manuscrito trata dos materiais utilizados para fazer a flecha e proporciona uma valiosa informação sobre como esticar o arco persa. A parte final do artigo explica as diferentes técnicas de disparo que se podem utilizar um arco composto persa.

Palavras-chave: Artes marciais persas; Artes marciais históricas; Arco persa; Arco composto; Tiro com arco.

*E-mail: bededw@tpg.com.au. 


\section{1.- Introduction}

A Persian archery manuscript entitled Resāle-ye Kamāndāri [Archery Manuscript] that was first introduced and published in Majjale-ye Barrasihāye Tārixi [Journal of Historical Researc] (1968, pp. 75-88) offers much interesting information on Persian archery techniques. This manuscript was found among ten manuscripts, each with a different handwriting in 1968. One is called The Selection of the Archery Manuscript written by Kapur Čand ${ }^{1}$ which had been reportedly collected in India before$^{2}$. The several Persian archery manuals that have been examined so far (Dwyer \& Moshtagh Khorasani, 2012; Moshtagh Khorasani \& Dwyer, 2012) ${ }^{3}$ have revealed that, despite being centuries apart in time ${ }^{4}$, there are many common features which they share. They describe archery in a technical manner that is consistent in approach and shares many details despite being by different authors. It would be reasonable to assume therefore that this represents a coherent tradition being reported by individuals with slightly different viewpoints.

The current manuscript is divided into functional sections though the break up is not wholly consistent. The main divisions are the archer, the bow, the string, the arrows, how to draw, aiming, problems with shooting and finally the names of the parts of the bow. The methodology used for the analysis of this manuscript is based on a comparative linguistic analysis of technical archery terms to other Persian archery manuscripts and period lexicons (see Moshtagh Khorasani, 2013: 66-93). Then all suggested techniques were put in practice by one of the authors of this article using a replica of a Persian composite bow.

\section{2.- Archer}

The qualities of the archer are discussed first in ten points. These points can be grouped into moral, temperamental and physical characteristics. The moral requirements are to be pure of heart and grateful to one's master, to not be greedy and to lead a pure life, to keep promises and to do good deeds. The archer also needs to be in a good mood and stand tall, and to be able to cope with suffering and be chivalrous. The physical features that are required are an open chest, wide shoulders and long arms.

Other qualities are mixed in with these. Frugality and obedience are enjoined. Oppression and insulting of people are discouraged. Finally, this art should not be taught to "the ungrateful, the stingy, delinquents, the abominable and bad characters". This list of characteristics actually exceeds the ten specified because some are grouped under one heading often without any logical connection such as long arms and frugality which are set next to each other. What is described is an exemplary paladin, the pahlavān of Iran, the perfect knight of European tradition or the faris of Arabic lore. To be an archer required restraint and dedication, high moral principles and respect for one's teacher. The tenth point, which includes at its end the list of the unacceptable types of people, is a warning to the reader not to proceed past this point if he approaches archery with the wrong mental attitude. The original text reads:

In the name of God, most benevolent, ever-merciful

The recognized archery books have described this science for those who want to learn as the following:

First, he should have a pure heart

Second, he should be thankful to the master

Third, he should be without greed and lead a pure life

Fourth, keeping promises and showing good deeds

Fifth, he should be in a good mood and stand tall

\footnotetext{
1 Entexāb-e Resāle-ye Qŏsiye Tasnif-e Kapur Čand انتخابرسالةقوسي-تصنيف كيورجندا.

2 This collection was given as a present [gift] by Mr. Hasan Ali Qaffāri (Mo'āvenoldolleh) to the Central Library of the University of Tehrān.

3 The full translations of these manuscripts are published in Moshtagh Khorasani (2013).

4 The archery part of the manuscript Nŏruznāme [Book of Nŏruz] by Xayyām Neyšāburi from the $11^{\text {th }}-12^{\text {th }}$ centuries, the manuscript of Šarif Mohammad from the early $16^{\text {th }}$ century and the manuscript Jäme al-Hadāyat Fi Elm al-Romāyat from the $16^{\text {th }}$ century.
} 
Sixth, he should be able to suffer and follow the principles of chivalry

Seventh, he should have an open chest and wide shoulders

Eighth, he should not be an oppressor and insult the people

Ninth, he should not be lazy and should be obedient

Tenth, he should have long arms and the owner should be frugal; the teaching of this technique is not recommended for the ungrateful, the stingy, the delinquents, the abominable and the bad characters.

Anyone who wants to be happy and plans to learn this chosen method should take the bow

handle from the hands of the master with honesty and full of dedication and start this sport.

This concept that an archer should be morally ascendant as well as physically skilled is not unique to Iran and can be seen in archery manuals from China as well. Stephen Selby has translated sections that parallel what has just been discussed from an early Chinese encyclopedia written in the Song Dynasty (960-1276 C.E.), but with the archery section printed in the Yuan Dynasty (12711368 C.E.). He translates it as "Archery's Ten Commandments" (Selby, 2000: 273-274). The gist is that the archer should not let his mind wander, not worry about other things, not arrive in a rush, not be drunk (a very important admonition when using weapons), not be distracted by hunger, not shoot after over eating, not be angry, not shoot when he does not want to, not get carried away shooting so that one does not want to stop and not to compete aggressively. It is not surprising that civilizations as distant as China and Iran should have similar ideas about the qualities of an archer.

The composite bow used in both places was a powerful weapon that needed great technical skill to build and understanding from the user's viewpoint to maintain it at its optimum. It was not a weapon you could just take off a rack and use immediately. It took thought and preparation. To shoot a bow requires calmness and self control. Aiming requires the archer to make minute adjustments to his posture while under great physical stress.

This in part explains why the qualities mentioned in the manuscript were important to become a good archer. Some of the qualities are what are needed in a good student. The archer had to be obedient and respectful to get the most out of his teacher. The technical requirements of the art are of such complexity that a good teacher can make all the difference between a competent archer and a truly effective one. Later in the manuscript there is a discussion of the difference between an arrow shooter (tirandāz تير انداز) and a bow puller (kamānkeš كمانكش). "The level of an "arrow shooter" is higher than a "bow-drawer" and the masters consider the bow pullers [below] the beauty of arrow shooters. Although the two words have an identical meaning in modern Persian, at the time of the manuscript there was a clear distinction between brute force and skill. It might also reflect that there were contests purely based on strength where the object was to pull a powerful bow rather than to shoot an arrow with it. In the Chinese military exams, there was a special section dealing with pulling bows of special weights. The candidate could improve his position in the exams by pulling heavier bows. In this case, there were even special bows made purely for drawing and not shooting (Selby, 2000: 352).

\section{3.- The bow}

The description of the bow is brief but complete and several important characteristics are mentioned. The standard size of the bow is given as six and a half spans ${ }^{5}$. This translated into modern measurements would be 1.24 meters (48.75 inches) which is a length compatible with surviving bows from Iran. This measurement is the length along the edge of the bow from nock to nock and does not vary because of the final shape the bow has settled into after use. The bow was perfectly symmetrical about the grip which confirms the views of authors like Taybugha ${ }^{6}$ in the fourteenth century. The description is as follows

\footnotetext{
5 The word used for span is وجب which can be translated as either a span or a palm. In Saracen Archery, Latham and Paterson derived a distance covered by a span as 7.5 inches (Latham \& Paterson, 1970: 160). They argue that the commonly used translation of 9 inches would be uncomfortable for an average man.

6 "They (sc. the Turks, Persians and Iraqis) divide the bow in half at the halfway mark on the grip so that whichever limb is the weaker is taken by them as the shooting limb (i.e. the upper)" (Latham \& Paterson, 1970: 17).
} 
He should make the bow such in a way that, if he hangs it from the bow grip with a string, both sides of bow limbs stand at the same level and the weight of one bow arm should not be lesser or more than the other.

This structure is consistent with Turkish bows that have been tested by Karpowicz (2008: 42 ) and one of the authors separately and also of several Indo-Persian bows. The advantage of this design is that slight inconsistencies in the strength of the limbs of the bow can be compensated for by simply reversing the bow in the hand. It is in contrast with earlier types of composite bows which sometimes had the upper limb longer to cause the center of the string to coincide with the arrow pass on the bow (Latham \& Paterson, 1970: 16-17).

\section{Figure 1}

Different parts of a Persian bow

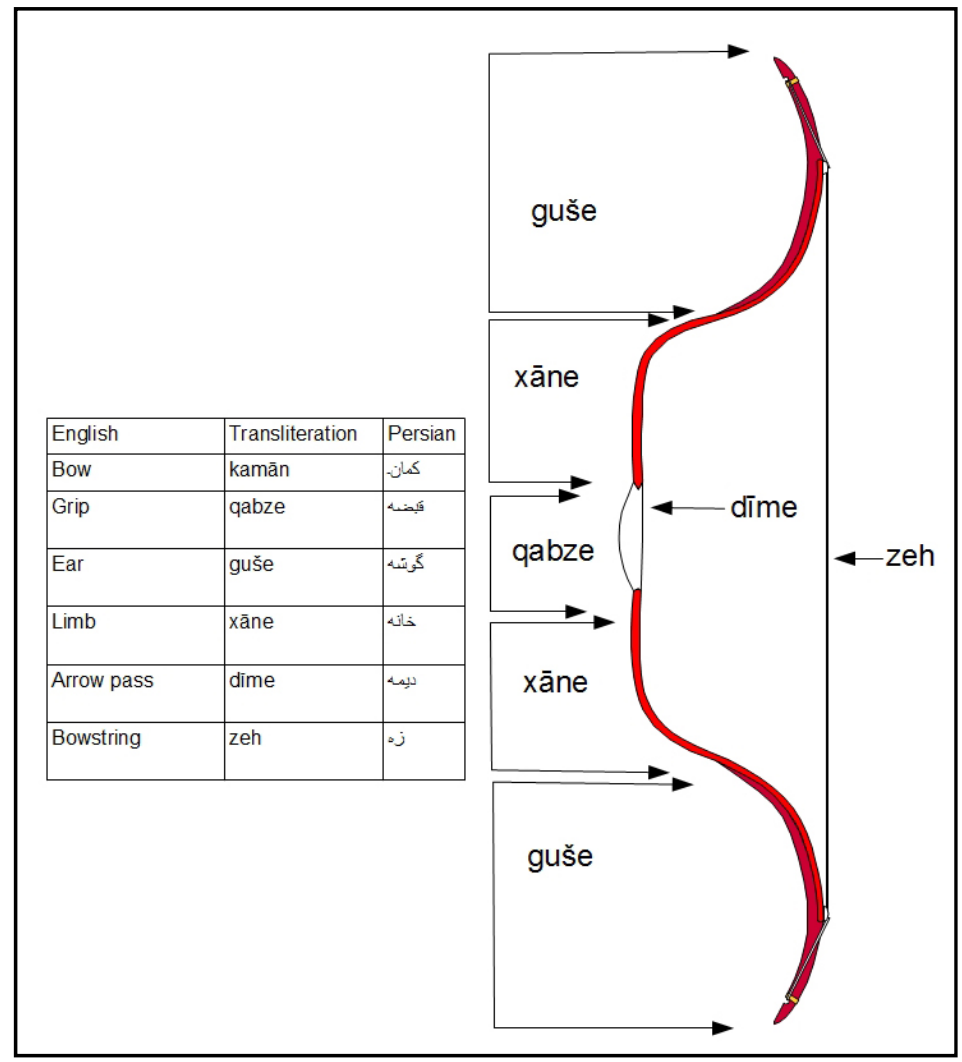

The bows were made with a wooden core reinforced by a pair of horn strips on the belly. The back was reinforced with sinew and the whole painted and varnished. What is interesting about the description of the manufacture of the bow is that unlike the description in another of the manuscripts and also specimens that have been dissected ${ }^{7}$, it had two paired horn strips instead of multiple parallel strips. There is a bow recorded in other manuscripts which might corroborate this design feature. Surviving examples come from Sind where they are known as four-curved bows ${ }^{8}$.

The author is careful to point out that the materials must be first class as can be seen from this quote:

The horn should be young, the wood should be pieces of mulberry and the animal glue and sinew should be clean. Both bow limbs should be made from a pair of horns and wood and in carving and filing he should be very careful.

\footnotetext{
${ }^{7}$ A dissection of a Persian bow with diagrams and description can be found in Balfour (1890: 231-235 and Figs. 9-16). This bow had parallel strips of horn on each limb.

8 The four-curved bow or čahär xam bow was also mentioned in Persian archery manuals. An article by Edward McEwen in Islamic Arms and Armour (Elgood, 1979: 89-96) titled "The chahār-kham or 'four-curved' bow of India" has a complete description of the class of bow with diagrams of its structure and a discussion of its manufacture. Aside from its unique profile, this bow had solid horn laminations under its wrapping of sinew just as described in the current manuscript.
} 
Following this section there is a very important observation of how the bow should feel when being drawn:

The method of achieving the way of the master is to have a bow that seems to be hard at the beginning of the draw and be easier at the end.

This seemingly simple comment refers to a subtle but important feature of reflexed and recurved bows ${ }^{9}$. When pulling back the string, the actual increase of pressure declines in the last part of the draw. In the first few inches of the draw the pressure might increase by two pounds per inch while in the last few the increase might only be one pound per inch. This has two consequences for the archer: the bow seems easier to draw psychologically because the increase in force is not linear and the bow stores more energy. The first makes drawing and aiming easier and the second delivers more energy to the arrow.

\section{4.- The Bowstring}

The bowstring material recommended by the author of the manual under discussion was silk and he specifies what features the bowstring should have. He writes that the strands should be straight and there should be no knots or kinks in the string. Kinks concentrate stress in the string and can lead to breakages and excessive twisting of the component threads of the string absorbs energy by increasing the stretch possible.

He recommends later in the text wrapping a little silk floss around the center of the string where the arrow nock is placed to ensure a tight fit. It is clear that he was talking about something separate from the serving ${ }^{10}$. As the diameter of the string is related to its strength (and that of the bow) ${ }^{11}$, this could indicate that arrow nocks were made a standard size rather than customized to each archer and his bow. This would be a natural development for war arrows where tens of thousands would be made and distributed to the troops. Target and flight arrows would be made for specific people and match their private equipment. Other references in this section make it clear that the author was talking about bowstrings made in the normal manner for silk strings with separate end loops and the so-called triple knot.

\section{5.- Arrows}

It is clear from this manuscript that the author was mainly concerned with reed arrows. Other translated manuscripts (see Moshtagh Khorasani, 2013: 66-93), are preoccupied with wooden arrows. This concentration on reed is a significant fact ${ }^{12}$, though its exact implications cannot be worked out without further research. Reed arrows are ancient in the Middle East; hundreds of them survive from Ancient Egypt. There are advantages to reed as a material for the shaft of an arrow since it has a high strength to weight ratio. The cultivation of varieties of reed for arrow production is documented in India (Elmy, 1969: 2). Being both easily grown and easily transported because of its lightness, reed was an obvious choice for arrows. However, it did have disadvantages like the difficulty in gluing to its hard, shiny surface layer. Most surviving reed arrows have the area under the feathers wrapped in sinew and painted to give a surface for gluing and also to strengthen the reed near the nock.

\footnotetext{
${ }_{9}^{9}$ A reflexed bow is one that curves away from the archer when unstrung. A recurved bow is one whose tips curve away from the archer when it is strung. A bow can be reflexed without being recurved if the string runs from one tip to the other without touching the bow limbs in between.

${ }^{10}$ Serving is thread wrapped spirally around a bowstring to prevent wear and to stop the threads separating.

11 Oriental bowstrings in general are thicker than western bowstrings such as those for English longbows. This is for two reasons: to resist the greater tension in the strung bow and to prevent breakage, which is a more serious event for a reflexed composite bow than a plain wooden one. The thinnest Oriental bowstrings are the Turkish flight strings. Iranian and Indian bowstrings are thicker as are Korean and Chinese.

12 It may reflect on where the manuscript was written and also suggest the relative abundance of suitable arrow wood to reed in that area.
} 
While Roman reed arrows from Dura Europos had self nocks ${ }^{13}$, almost all surviving reed arrows from the Indian subcontinent have applied nocks in wood, bone or ivory. Ancient Egyptian reed arrows have both nock inserts and hardwood footings at the other end of the arrow.

The text advises using the root end of the reed as the nock end of the arrow and describes a method of determining the correct end if the reed is already cut. It relies on the root end being denser than the tip ${ }^{14}$. Arrows made this way would exhibit a slight taper from nock to the base of the arrowhead. The diameter of the stalk of a mature reed does not vary greatly judging from old arrows, but, by constructing an arrow in this manner, the nock could be cut from the thicker part of the reed. However, most surviving Persian and Indo-Persian reed arrows have inserted nocks of hardwood, bone or ivory so this choice of where to put the nock must have worked with applied nocks too. One suggestion is that the thinner foot of the arrow is strengthened internally by the tang of the arrowhead so it never needed the more robust section of the stem while at the nock end the shaft had to be scraped of its outer skin so an extra thickness would be an advantage. The opposite strategy is found in the book, Arab Archery, where for wooden arrows it is recommended the base be used as the end to attach the arrowhead (Faris \& Elmer, 1945). This might simply be a difference required by different materials. A casual examination of the tangs of arrowheads shows that those meant for reed and bamboo usually had longer tangs so the reinforcing effect would be less for the shorter tanged arrowheads used with wooden shafts ${ }^{15}$.

Surviving Persian reed arrows from the Zand period (1750-1794) range from 75 to $83 \mathrm{~cm}$ long (Moshtagh Khorasani, 2006: Cat. 491-502). The manuscript recommends measuring the archer's personal arrow length by finding the distance from his shoulder with his arm outstretched to the tip of his index finger. However, this would be too short for many people and it would be inconsistent for people of different physical proportions ${ }^{16}$. One more thing can be said about the method mentioned in the manuscript which is not related to its physical relevance. Many archery manuals in Arabic go into great detail about how to work of the length of the arrow based on the archer or the bow using some esoteric calculations (see Klopsteg, 1934, 1947, 1987: 54, and Latham \& Paterson, 1970: 20-21), but often incidentally mention the most obvious way which is to have the archer draw a bow in the correct manner and measure the length that the arrow is drawn. This last method can easily be derived from the information given on the draw later in the manuscript.

\section{6.- Bracing the bow}

There is a short section on how to brace or attach the string to the bow. With reflexed composite bows this is not the easiest operation. The problems are twofold. The first is strength and leverage. The bow, without its string, curves away from the archer so it is necessary to bend it until it is nearly straightened out before the archer has any leverage. In the initial state, the bow needs considerable force to move its limbs to the proper position to attach the string. Second is the

\footnotetext{
13 Self nocks are nocks cut into the material of the arrow shafts rather than being cut into another piece of wood glued into the hollow reed shaft. Many wooden arrows have self nocks, but reed arrows and modern arrows usually have separately attached nock pieces. In modern times even wooden arrows are regularly prepared by having plastic nocks glued onto the shaft. For the arrows excavated at Dura Europos in modern Syria see James (2004:95-96). Items 720-741 refer to fragments of reed arrows excavated at the site.

14 The shaft was balanced on the finger and tossed in the air. Whichever end landed first was considered the root end. One could also float the shaft on the surface of some water and note which end was lower.

15 This observation has been made by one of the authors comparing archaeological examples from China where there was a change from a mainly bamboo arrow technology to a mainly wooden one for historical and ethnic reasons. The early periods when bamboo arrows predominated are characterised by finds of arrowheads with long tangs compared to their body length. However, in the Qing Dynasty when wooden arrows were mandated, the tang usually was comparable in length to the rest of the arrowhead. There were exceptions to this observation since arrowheads were designed for specific purposes and therefore had longer or shorter tangs as required.

16 One of the authors compared his arrow length as calculated by the manual's system with the arrow length required by the physical limits described in the section on drawing the bow. The manual recommended $66 \mathrm{~cm}$ while the actual draw length was $76 \mathrm{~cm}$. A taller person would have longer arrows. Coincidentally, the first measurement is a common length for Turkish arrows used with a siper (overdraw device) and is also the length of the Turkish gez (a length of measurement).
} 
need to keep the bow arms correctly aligned so no twist develops. The manuscript has a solution which requires an assistant. The archer puts his knees on the bow limbs on either side of the handle and reaches forward to grasp the ears of the bow. When he has pulled the bow back sufficiently, his assistant slips the loops of the bowstring over the tips and into the nocks of the bow. This system is so effective that it is still used to brace composite bows today and is still practiced in Mongolia ${ }^{17}$.

The description in the text has some difficulties since it is possible the author transposed some terms, particularly when he describes testing the bow after bracing, but there is no misunderstanding the sense of his instructions. It appears he pulls the bow a little so that the string moves away from the bow and at the same time he checks to see how far it lifts off the string bridges ${ }^{18}$.

\section{7.- Shooting}

The rest of the manuscript concentrates on how to shoot an arrow with the bow with a final digression on the nomenclature of the bow. Shooting can be divided into several processes that occur roughly in order. The manuscript divides them as follows: a) Standing before the target; b) Grasping the bow; c) (Nocking) Attaching the arrow onto the bowstring; d) Locking the thumb onto the bowstring; e) Drawing the arrow back to full draw; f) Aiming and g) Releasing the arrow.

The stance of an archer is an obvious indication of his understanding of shooting. A clumsy or ineffective stance would mark out a beginner or amateur. A regular and graceful stance based on one of the schools of archery would show the skill of the archer while ensuring a stable starting position for each shot. The author recommends a stance with the left foot pointing towards the target while the right is behind it at right angles. The left leg is relaxed while the right leg takes all the weight. To align his shoulders with the target, the archer twists slightly at the waist. A poem is quoted to illustrate this:

Place your arrow at the beginning of the channel

Twist a little at the waist and hold both shoulders rigid.

As for grasping the bow in the hand, the manuscript describes three possible positions for the hand, the hawk's claw grasp, the bahrāmi ${ }^{19}$, and the square grasp. These differ in the relative positions of the thumb and other fingers as well as how the bow sits in the palm. They all share the same position for the middle, ring and little fingers which are tightly in contact with the bow handle. In a subsequent discussion of injuries, it is made clear that the thumb and index finger should not be tensed. Some details are explored of what injuries to the archer are caused by what faults in holding the grip of the bow. However, without experience in this form of shooting the explanations can be little vague as follows:

If they ask why upon opening the thumb, the bowstring strikes the forearm and injures it, answer, this is due to three reasons: First is when he grasps the bow handle in the palm of his hand; Second, holding the bow in a way that the upper bow ear tends towards the left; Third, when he opens from the right hand and keeps the left hand firm.

The first means that the archer has seated the belly of the handle in the palm of his hand rather than supporting it with the area between the bases of the thumb and index finger, causing the bow handle to be at the wrong angle to the forearm. The second is caused by twisting the bow hand so that the upper limb leans to the left bringing the string in close to the forearm when it is released. The third refers to maintaining tension in the left hand which can accidentally turn the bow and cause the string to impact the arm. This brief example shows the complexity of diagnosing shooting faults since a similar effect can come from three divergent causes.

\footnotetext{
17 One of the authors uses this system regularly to brace composite bows since it is safe for the bow because it prevents twisting of the limbs.

18 čakāvgāh جكاو

19 Named after Bahram V (ruled 421-438), a Sasanian king who was famous for his archery exploits.
} 

identified:

After several more examples of faults, the author quotes a master archer who is not

The master says: three things should be tense, three things loose, three things soft, three things should be straight and three other things where two are considered one.

This summary of tension and relaxation, alignment and coordination is then explained in detail. This is a common method for remembering important features of shooting that is used in other archery manuals including Arabic and Turkish ones. A couplet of poetry or a short list is memorized and the detail recalled when needed. Mnemonics like this are still used today to remember more complex ideas in physics often in the form of acronyms.

The section on nocking is equally detailed and important. Modern archery does not concentrate on this process and archers often put their arrows on the string in ineffective and clumsy ways. However, modern horse archers have learned the importance of nocking carefully and developing a standard practice for it since at the gallop there is no time to look down at your bow and laboriously fit the nock to the string. This was undoubtedly important in the days when archery was used in warfare as well 20 .

Nocking is closely associated with locking the thumb around the bowstring and these two practices are explained in their logical order. Several faults are described and proper practices are explained. While the description of the thumb lock agrees with Arabic, Turkish and Chinese manuals, it diverges from some modern methods of using the thumb so it might be worthwhile to summarize the method as it is described.

The middle, ring and little fingers are tense. The thumb presses against the middle finger and the middle segment of the index finger rests on the tip of the thumb covering the top of the thumb nail and exposing the base of the nail. It is implied that the arrow nock does not sit directly on the thumb at the beginning of the draw, but is free to move with the string as the bow is drawn ${ }^{21}$.

Drawing is accompanied by lists of what should be done. It is clear that this was an important subject and much work had been done on perfecting technique. Three things that should be aligned are the arrowhead, the drawing hand thumb and the right elbow making the arrow effectively and extension of the forearm. Even without conscious aiming, instinctively the archer would be pointing the arrow at the target.

There are four parts to the art of drawing a bow:

a) Keeping the body and the bow upright;

b) Drawing in a straight line;

c) Drawing as far as the ear and

d) Drawing smoothly and evenly.

Many faults are listed in this extensive section but they can be overcome by using a bow of appropriate strength, a firm grasp on the bow, proper stance and correct alignment of the body. A short poem describes the proper distance the arrow should be held in relation to the face:

There are eyebrow-draw, chest-draw and moustache-draw. Leave the eyebrow and the chest and do a moustache-draw.

Two of these positions survived in Mongolia into the twentieth century proving the ubiquity of the techniques and recently the equivalent of the moustache draw has become predominant ${ }^{22}$.

\footnotetext{
${ }^{20}$ A good example of this can still be seen in the modern discipline of Yabusame as practised in Japan. Even Kyudo, traditional Japanese target archery, retains attention to detail in nocking.

21 This is consistent with Mușțafā Kānī's instructions (Klopsteg, 1934, 1947, 1987: 96). While the nock is not in contact with the thumb at first, the side of the index finger gently keeps it in place. As the string's angle to the arrow decreases as the draw progresses, the arrow is lowered onto the thumb. It is possible at the end of the draw to remove all pressure on the arrow and this is essential in flight archery.

22 The changes in modern Mongolian technique are analysed in Batkhuyag (2008: 29-33). The three draw levels are chest, chin and lips. There is no equivalent of the eyebrow draw since it is impractical due to the distances the Mongols shoot their heavy arrows.
} 


\section{Miniature 1}

A miniature titled "Alexander is killing the dragon and finds out about his upcoming death" from a 10th-century Hegira (16th century C.E.) Šăhnāme manuscript known as Borhān manuscript shows the technique sormekeš (eyebrow draw) (Courtesy of the University Library of Tehrān).

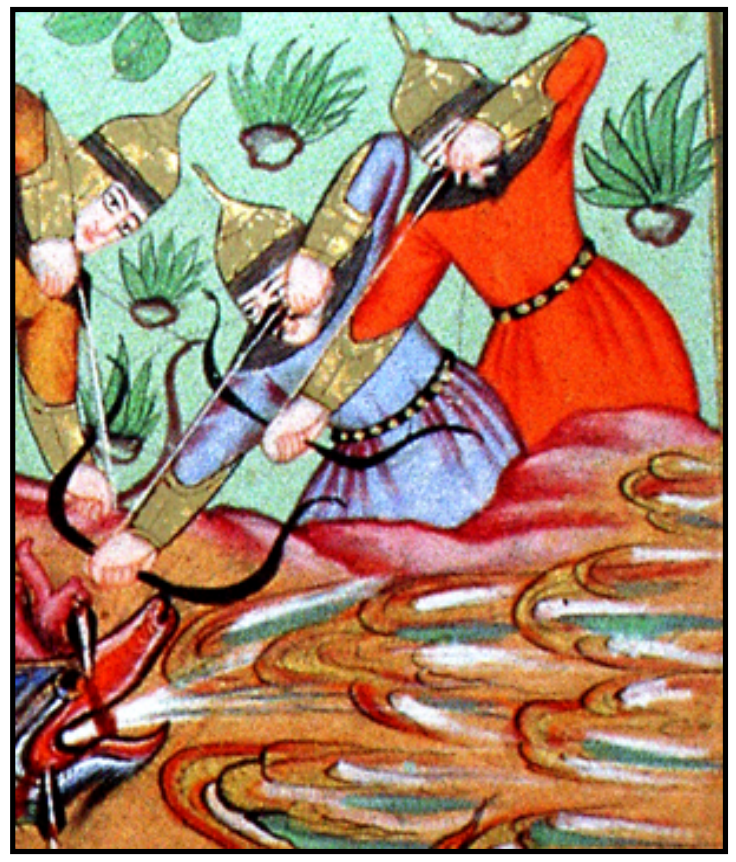

Miniature 3

In a miniature from the Timurid-era Šāhnāme-ye Bāysonqori, some archers are shown who are shooting with the technique borutkeš (moustache draw).

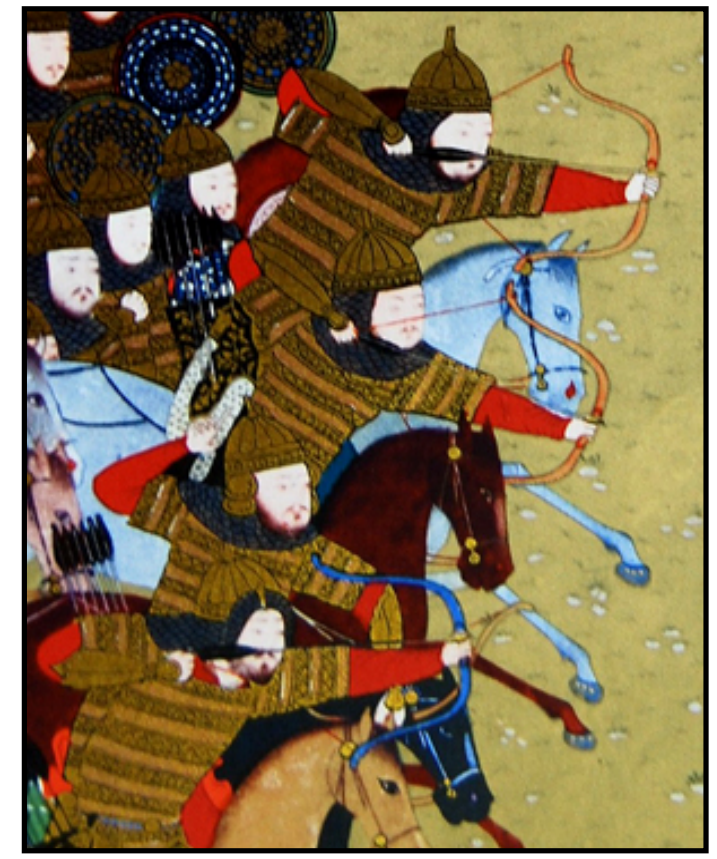

\section{Miniature 2}

A miniature titled "Bātu and his companions pray to the Sun God for victory in the manner of his grandfather Čangiz Xān" from the 1596 manuscript Jāme al-Tavārix shows archers on both sides on the riverbank who are shooting at each other with the technique sinekeš (chest draw) (Courtesy of Golestān Palace Museum).

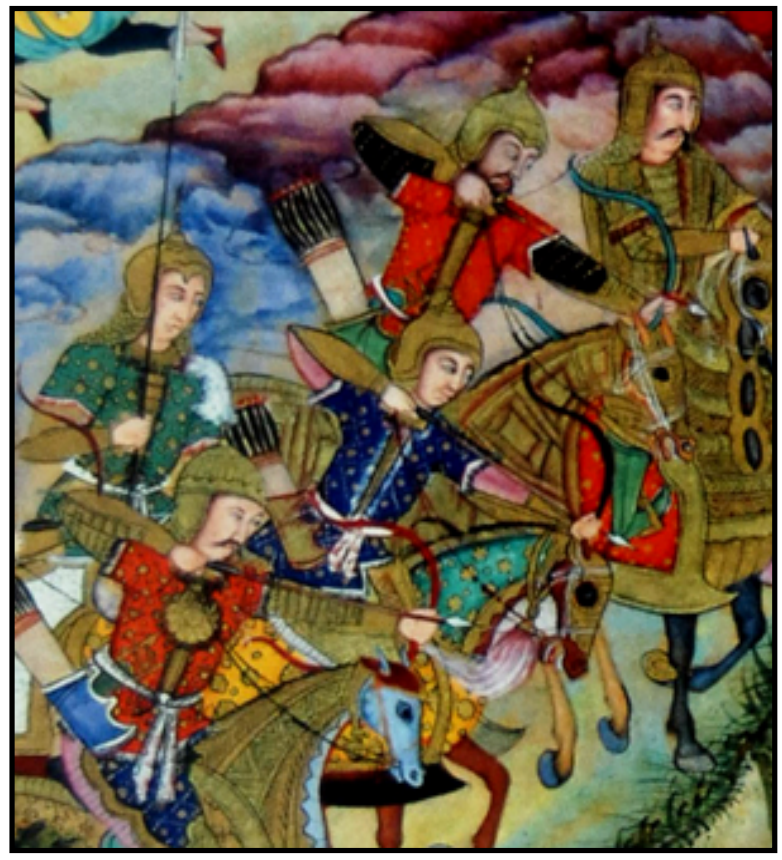

\section{Miniature 04}

A miniature from a 10th-century Hegira (16th century C.E.) Šāhnāme manuscript shows the technique borutkeš (moustache draw) during battles between Iranians and Turanians (see Bāqer Najafi, 1997/1375, plates 146-147).

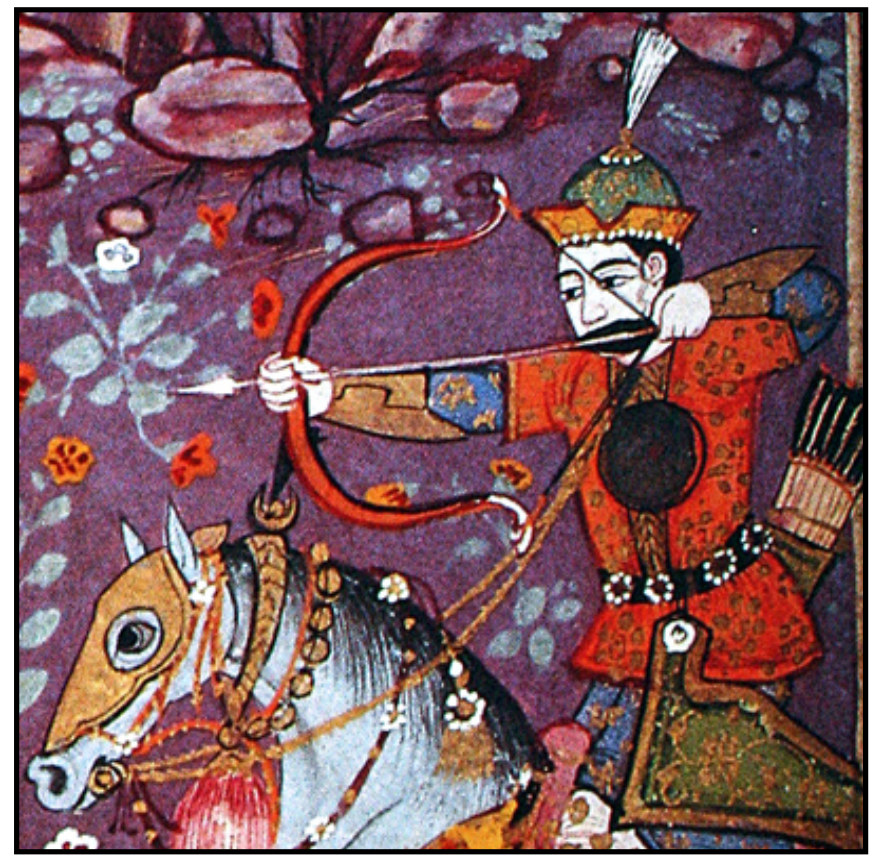


The section on aiming contains some important information that can be used to estimate the efficiency of the bows used at the time the manuscript was written ${ }^{23}$. It has a description of the elevations the arrow should be shot from at various distances. The measurements are given in gaz, which might be problematic, but a minimum distance can be calculated ${ }^{24}$. The method is to describe what finger of the hand holding the bow should be aligned with the target. For instance, assuming the moustache draw with the nock of the arrow drawn to the ear, there is a definite relationship between what finger of the bow hand is opposite the target from the archer's point of view and the angle to the ground that the arrow is being held. This is like a modern archer using a graduated sight. Here is an example of an instruction for aiming:

If the target is at one hundred gaz, he places the index finger and the arrowhead towards the heart of the target and releases it.

In modern shooting parlance this would be called 'point blank'. There are instructions for distances up to $400 \mathrm{gaz}$ sighting with the middle finger, then the ring finger and finally the little finger ${ }^{25}$.

There is a special section relating to the position of the arrowhead at full draw since this is one of the three things that set the accurate placement of the arrow. The other two are where the arrow crosses the face (e.g. the moustache) and where the drawing hand stops at the ear. The main thrust of the section is on how the draw is completed and it contains descriptions of the dynamics of the draw. Here is an example of the instructions:

Thus, he should first draw slowly until the arrowhead comes close to the bow handle, [then] he puts a new force and with absolute dexterity and speed he brings the arrow nock to the ear and the arrowhead at the same level of the bow handle and then releases it [the arrow].

This is a description of an advanced archery technique called the "snatched 26 " in Arabic (Latham \& Paterson, 1970: 64). The draw starts in a measured manner until about a hand's width of the arrow is left to draw and is finished with a sudden movement. The current author likens the last quick move to how fast one pulls ones hand away from hot food. This is a way to minimize the time that the arrow is at full draw so that none of the bow's energy is lost in holding too long. This is a difficult technique since it requires split second judgment by the archer. He must release as soon as the arrow reaches the back of the grip. If he releases early, the arrow will fall short of the target or hit low. If he releases late, he may have pulled the arrowhead inside the bow so that its tip hits his hand or the belly of the bow grip. This is not a technique for average archers. The last problem is addressed in a technique called 'shooting from the top of the sleeve' when it is done on purpose. What is a fault when it happens unplanned can be an advantage when it is done deliberately. Master archers could overdraw an arrow this way to gain extra distance in flight shooting, but it was very dangerous.

The last part of the discussion on aiming treats with problems in shooting at a target. Such things as hitting ones beard with the bowstring or putting too much pressure on the nock are explained and their remedies are given. There is a rare mention of breathing, which does not have the prominence in archery manuals in the Middle East that it does in the Far East. The archer is instructed not to breathe in while drawing the bow and to breathe out as he releases. This would keep the chest steady and expanded. The archer is advised to keep his attention focused on the target from the beginning of the draw until the arrow is released. Observations on various methods

\footnotetext{
${ }^{23}$ It is possible this section is a paraphrase and not an original observation. If it is a quotation, it might refer to a different time or place.

24 The Ottoman gez and the Persian gaz are the same written word, but the measurements vary and it is possible that there was an international standard archery measurement shared between Turkey and Iran. However, at this stage of research, this is purely speculative. The Ottoman gez is defined in Türk okçuluğu as $66 \mathrm{~cm}$ (Yücel, 1999: 399). This is smaller than the generally used value of the Iranian gaz, but it can be used for conservative estimates.

25 In case this might be thought to be either esoteric or merely a theoretical method, one of the authors has observed traditional Mongolian archers using the same system. Which finger to use is relative to the speed at which an individual bow shoots an arrow just as with a modern archery sight.
}

${ }^{26}$ Mukhtalas مختلس. 
of aiming are made including references to Tāher Balxi (the famed Persian archer), the great master archer, and to the Jats (an ethnic group) of the Punjab.

\section{Miniature 5}

A miniature titled "The battle of Humān and Pirān Veyse" from a manuscript of the Rašidā Šāhnāme from the first half of the 17th century C.E. shows how the mounted archer on the left has shot and hit his mounted opponent in the belly with an arrow with the technique tir bar šekam zadan (to hit the belly with an arrow) (Courtesy of Golestān Palace Museum).

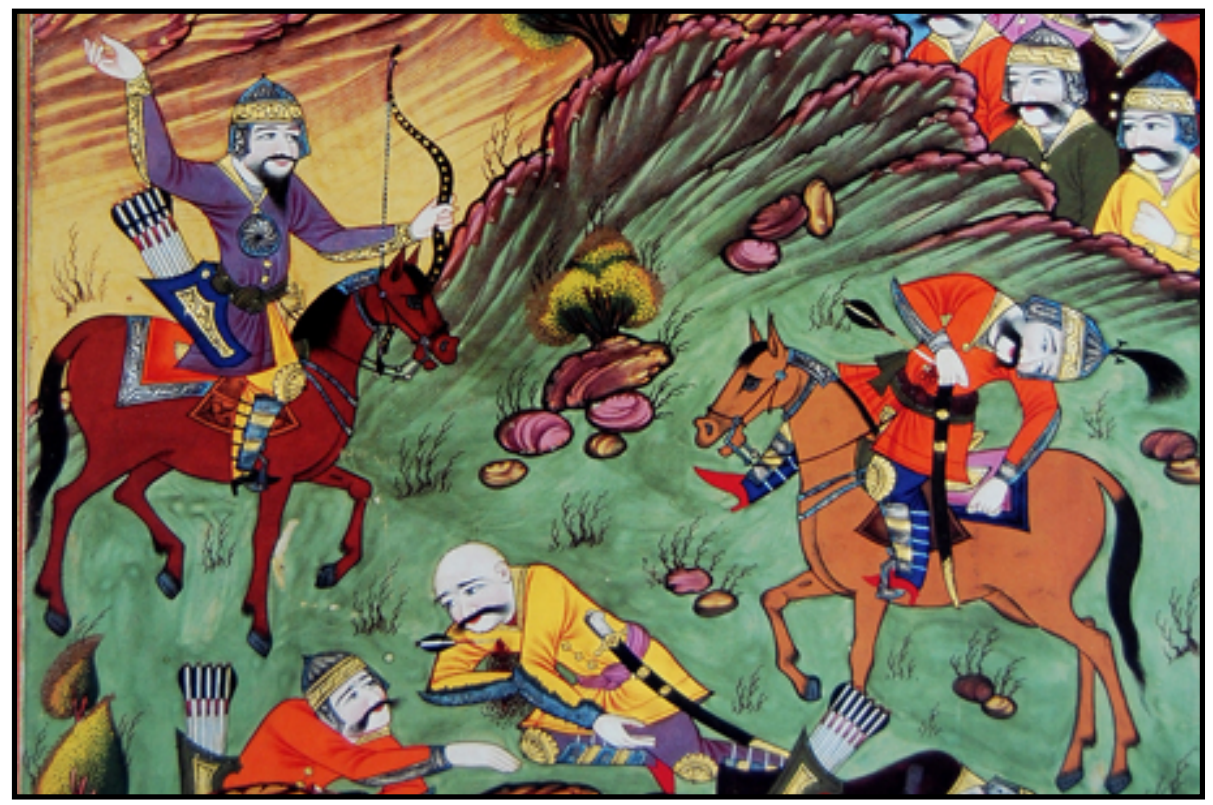

Finally there is a description of the names of the parts of the bow which one would imagine belongs with the discussion of bows. This is a valuable addition to archery nomenclature since these names will undoubtedly turn up in other manuscripts.

\section{8.- Conclusion}

This short manuscript is both a technical document of great value for the study of Persian archery and also an interesting example of a writing style. Despite being remarkably clear and concise, it is interspersed with fragments of poetry carefully chosen to illustrate important ideas. While it may not be of great literary merit in the larger world of Persian prose, it has a basic honesty of purpose and a utility of execution that makes it both interesting and useful. Valuable technical advice can be found for the practicing archer that is still understandable today. Observations of the functioning of the bow in use show the author was aware of fine details of performance in a purely technical sense and was able to communicate this both to archers of his own age and also to modern archers who recognize valid ideas.

The archer, who has to be so physically balanced in pulling a powerful bow and directing a slender arrow, also needs to have a moral and emotional balance. Self control and emotional maturity are just as important as strong arms and a good physique. This sophisticated view of a martial art resonates across different cultures linking Iran to other great civilizations.

\section{References}

Balfour, H. (1890). On the Structure and Affinities of the Composite Bow. The Journal of the Anthropological Institute of Great Britain and Ireland, 19, 220-250. 
Bāqer Najafi, S. M. (1997). Šāhnāmehāye Irān: Handschriften-Sammlung von Firdusis Schahnameh im Iran [The Manuscripts of Šāhnāme Ferdŏsi in Iran]. Bonn: Botschaft der Islamischen Republik Iran.

Batkhuyag, S. (2008). Issues of Mongolian Archery Shooting Techniques. In N.-S. Lee (Ed.), World Traditional Archery Historical Analysis and Future Orientation (pp. 29-33). Cheonan: Seung Jo Yang.

Dwyer, B. \& Moshtagh Khorasani, M. (2012). Jāme al-Hadāyat Fi Elm al-Romāyat [Complete Guide Concerning the Science of Archery]. Quaderni Asiatici, 97, 45-60.

Elgood, R. (Ed.). (1979). Islamic Arms and Armour. London: Scolar Press.

Elmy, D. (1969). Indian Arrows. Journal of the Society of Archer-Antiquaries, 12, 5-10.

Faris, N., \& Elmer, R. (1945). Arab Archery. Princeton: Princeton University Press.

James, S. (2004). Excavations at Dura Europos 1928-1937 Final Report VII: The Arms and Armour and other Military Equipment. (Vol. VII). London: The British Museum Press.

Karpowicz, A. (2008). Ottoman Turkish Bows Manufacture and Design. Canada: Adam Karpowicz (Self Published).

Klopsteg, P. (1934; 1947; 1987). Turkish Archery and the Composite Bow (3rd (1987) ed.). Manchester, United Kingdom: (Paul Klopsteg) Simon Archery Foundation.

Latham, J. D., \& Paterson, W. F. (1970). Saracen Archery. London: The Holland Press.

Moshtagh Khorasani, M. \& Dwyer, B. (2012). A Persian Manuscript on Archery, Spear Fighting, Sword Tempering and Lance Fighting and Horsemanship by Šarif Mohammad the Son of Ahmad Mehdi. Pan-Asian Journal of Sports \& Physical Education, 4(1), 1-17.

Moshtagh Khorasani, M. (2006). Arms and Armor from Iran The Bronze Age to the End of the Qajar Period. Tübingen: Legat Verlag.

Moshtagh Khorasani, M. (2013). Persian Archery and Swordsmanship: Historical Martial Arts of Iran. Frankfurt am Main: Niloufar Books.

Selby, S. (2000). Chinese Archery. Hong Kong: Hong Kong University Press.

Yücel, Ü. (1999). Türk okçuluğu [Turkish Archery]. (D. Ayan, Ed.) Ankara: AYK Atatürk Kültür Merkezi Başkanlığı.

\section{Authors' biographical data}

Bede Dwyer (Australia) has pursued his interest in oriental archery for approximately 36 years of his adult life. In that time, he has researched the archery traditions of Turkey, Mamluk Egypt, Iran, Northern India, Mongolia, China and Korea. Rather than just compile information from old books, Bede has actively tested equipment and techniques and makes archers' rings, arrows, quivers and bow cases. Bede was the first person to shoot an arrow guide of the style of a Persian nāvak (Arabic majrā) in the American Flight Archery Tournament at Bonneville Flats in Utah. Bede also uses the Ottoman siper overdraw in flight shooting and briefly held a world distance record for shooting a hunting arrow with a traditional composite bow. For more than a decade Bede has been publishing articles in the Journal of the Society of Archer-Antiquaries on archaeological remains of archery equipment ranging from ancient repeating cross bows to medieval closed quivers. He is an active member of Razmafzar Organization dedicated to the study and academic research on historical Persian arms and armor and martial arts. E-mail: bededw@tpg.com.au

Dr. Manouchehr Moshtagh Khorasani (Germany) has written five books (four related to arms and armor), co-authored one book, and 106 print articles on Persian arms and armor published in different journals across the world. His books include Persian Archery and Swordsmanship: The Historical Martial Arts of Iran, Lexicon of Arms and Armor from Iran: A Study of Symbols and Terminology (Winner of the World Book Prize of Islamic Republic of Iran 2012), Antique Oriental and Arab Weapons and Armour: The Streshinskiy Collection, The Development of Controversies: From the Early Modern Period to Online Discussion Forums and Arms and Armor from Iran: The Bronze Age to the End of the Qajar Period (Winner of the World Book Prize of Islamic Republic of Iran 2009). He is the founder and an active member of Razmafzar Organization dedicated to the study and academic research on historical Persian arms and armor and martial arts. E-mail: manouchehr@moshtaghkhorasani.com 